\title{
MORRISON ECOSYSTEM PROJECT
}

\author{
CHRISTINE TURNER $\downarrow$ FRED PETERSON \\ U.S. GEOLOGICAL SURVEY $\downarrow$ DENVER $\downarrow$ CO
}

\section{INTRODUCTION}

The Late Jurassic Morrison Formation is one of science's best windows into the world of dinosaurs and Mesozoic ecosystems. The Morrison Formation has significant exposures in many units within the Rocky Mountain Region of the National Park Service. These include Arches National Park (ARCH), Bighorn National Recreation Area (BIHO), Black Canyon of the Gunnison National Monument (BLCA), Capitol Reef National Park (CARE), Colorado National Monument (COLO), Curecanti National Recreation Area (CURE), Dinosaur National Monument (DINO), Glacier National Park (GLAC), Glen Canyon National Recreation Area (GLCA), Hovenweep National Monument (HOVE), and Yellowstone National Park (YELL)

The Morrison Formation Extinct Ecosystems Project, hereafter called the Morrison Project, began on June 1 of 1994 . The project is a multidisciplinary endeavor to determine the nature, distribution, and evolution of the ancient ecosystems that existed in the Western Interior of the United States during the Late Jurassic Epoch when the Morrison Formation and related rocks were deposited. The information obtained from the research can be used to suggest appropriate resource management actions and the project will also provide an improved understanding of the geological and paleontological history of these NPS units and better information for interpretive programs and publications.

\section{$\downarrow \quad$ METHODS}

The multidisciplinary project brings a variety of expertise to bear on a complex continental ecosystem in order to provide constraints from different disciplines to the interpretation of the ancient habitat of the Late Jurassic dinosaurs. The various methods of study include stratigraphic, sedimentologic, isotopic, paleontologic, geochemical, mineralogic, and pedogenic techniques of analysis. Each type of study has a unique and complementary role to play in the unravelling of the ancient ecosystem.

Stratigraphic studies provide the framework for correlation and comparison of the various types of data. Vertical sections through the Morrison Formation are measured for regional stratigraphic and sedimentologic purposes and also for control on the geographic and stratigraphic positioning of the samples that are collected for paleontologic and geochemical analyses.

Absolute dating of the Morrison Formation and its members is achieved through isotopic dating techniques. Tuff beds (altered volcanic ashes) yield mineral grains that are amenable to dating by two somewhat different techniques (single-crystal laserfusion ${ }^{40} \mathrm{Ar} /{ }^{39} \mathrm{Ar}$ and ${ }^{40} \mathrm{Ar} /{ }^{39} \mathrm{Ar}$ plateau methodologies). Several aspects of the mineralogy and geochemistry of the altered ashes also yield some information about their original compositions, which in turn tells us about the source 
area of the volcanic ash.

Relative dating of the Morrison is possible because of the evolution of microfossils through time. Charophytes (lacustrine algae), ostracodes, and palynomorphs are recoverable from various units in the Morrison Formation.

Detailed sedimentologic studies are undertaken on the range of depositional styles in the formation, including shallow marine, fluvial, overbank floodplain, swamp, and lacustrine depositional environments as well as and fossil soils (paleosols). Studies of plant taphonomy will yield additional clues to the nature of the paleoclimate.

Detailed studies of freshwater gastropods are also underway. Examination of the sedimentology of the gastropod-bearing lacustrine interval will allow a comprehensive analysis of the snails and the environment in which they lived.

The study of trace fossils in the Morrison helps to identify the position of the ground water table with respect to the ancient ground surface.

Isotopic analyses of carbonate nodules from paleosols is being investigated to determine the $\mathrm{pCO}_{2}$ (partial pressure of carbon dioxide) of the Late Jurassic atmosphere and to aid in reconstructing the ancient landscape.

Studies of microvertebrates are another important aspect of the multidisciplinary study of the Morrison Formation. Their living habits often yield more information about an ecosystem than the larger vertebrates. Another objective of the project is to pursue studies of important dinosaur specimens, with particular emphasis on new specimens.

The integration of the results from each of these studies is the ultimate goal of the project.

\section{PRELIMINARY RESULTS AND INTERPRETATION}

Although the interpretations thus far are preliminary and therefore tentative, some interesting new information about the Morrison ecosystem is already emerging.

Stratigraphically, the formation was studied in detail in the southern part of the Western Interior region and reconnaissance surveys were made as far north as Montana. At Dinosaur National Monument, it was determined that the lower contact of the formation may be a simple depositional contact rather than an unconformity as previous workers had thought. The nature of the upper contact has been clarified considerably and appears to be a regional unconformity. Some beds, previously assigned to Lower Cretaceous formations, actually are part of the Morrison and are Late Jurassic in age. Work in the type area of the Morrison and Ralston Creek Formations near Denver demonstrate that both of these formations correlate with the entire Morrison Formation farther west on the Colorado Plateau. These represent important refinements and corrections to the boundaries of the Morrison Formation, which are significant because the stratigraphic framework is the basis for the comparison of all other data gathered during the project. Progress was also made in establishing criteria for distinguishing between the Upper Jurassic Morrison Formation and overlying Cretaceous strata on the Colorado Plateau.

Research by ${ }^{40} \mathrm{Ar} /{ }^{39} \mathrm{Ar}$ isotopic dating methodologies indicates that the formation was deposited during an approximately 8 million year time span from about 155 to 147 Ma. More samples were collected to better date the formation and to gain an understanding of the nature of the unconformities at the base and top of the Morrison. Geochemical studies of mineral grains recovered from the bentonite beds indicate that the volcanoes that furnished the ash were rhyolitic in composition. This is consistent with the origin of the ash deposits in a volcanic belt above the subduction zone that extended along the west coast of North America during the Late Jurassic.

Studies of spores and pollen (palynology) resulted in dating of the various members of the Morrison Formation. The research showed that the bulk of the formation is Kimmeridgian in age whereas the lowermost beds are latest Oxfordian and the upper beds are Tithonian in age. These determinations allow us to relate the Morrison ecosystem to the rocks of similar age around the world.

Research on charophytes and ostracodes resulted in age determinations that correspond closely with that obtained from the palynomorphs. Other conclusions derived from these organisms 
suggest that standing bodies of water in which strata in the middle of the formation were deposited were somewhat brackish whereas the water bodies that were present during deposition of the lower and upper beds largely consisted of fresh water. More salinity-tolerant genera existed in northern Colorado and northeastern Utah than farther south or north, which might also reflect the nature of water bodies in these areas. These organisms also suggest a gradual cooling of the climate during Morrison deposition.

Sedimentologic studies for the first year indicated that the lower part of the Morrison Formation in the central Utah area were deposited along an ancient shoreline. A well-developed paleosol was documented at the top of the Morrison. Detailed studies of the depositional environments in the area around Cañon City, Colorado, were integrated with trace fossil studies of the same rocks.

A compilation was made of all known plant and animal fossils that have been recovered from the Morrison Formation anywhere in the Western Interior. The listing will be an important asset for use in analyzing Morrison life forms, associations, and population dynamics in the Morrison ecosystem.

Several types of freshwater gastropods have been recovered and identified from the Morrison Formation. The terrestrial snails provide information on the nature of the ecosystem because some of them (prosobranchs) were gill breathers that lived only in aquatic habitats whereas others (pulmonates) were lung breathers that lived either in shallow water or could survive on dry land or on the vegetative cover. Similar studies will be made of the bivalves in the Morrison because they also yield clues to habitat.

Studies of trace fossils that can be related to specific organisms demonstrate that crayfish, termites, bees, and other insects were common in the Morrison ecosystem. Assemblages of these traces along with studies of paleosols can be used to define the position of the ancient water table with respect to the land surface. This gives a rough idea of soil moisture as well as whether or not permanent water existed at shallow depths and was therefore available to the plant community. The position of the original ground water surface is established by the tops of the burrows made by the burrowing bees, other insect burrows, and the tops of the crayfish and termite borrows. The position of the water table is determined by a combination of crayfish burrows, which extend down below the water table (so the crayfish can keep their breathing apparatuses moist), and by termite nests, which extend into the capillary fringe (for thermal regulation) but do not extend down to penetrate the water table (being air breathers, they would drown if the water table rose above their nests).

Numerous samples were collected during the summer field season for analyses of stable isotopes and are undergoing laboratory preparation and analysis. Stable isotopes yield information on the ancient climate, plant community structure, weather patterns, storm tracks, temperature, trophic levels, and eating habits of the vertebrate land animals. Samples of paleosols (ancient soils), lacustrine units, dinosaur fossils, and groundwater mineralizations are collected. In the laboratory, subsamples are then selected for thin section analysis, isotopic analysis, or other analyses as needed. The stable isotope composition of organic matter from paleosols adjacent to fluvial channels is being contrasted with that of floodplain paleosols to see if there are indications of riparian zone canopy development. This yields information on the vegetative structure of the forest, which plays an important role in determining feeding strategies for the various animals. Lacustrine carbonates are being analyzed isotopically to investigate trends in oxygen isotopic values that might indicate changes in environments resulting from weather patterns, storm tracks, and global temperature. Isotopic analyses of dinosaur bone, tooth, and eggshell are underway that could yield information on trophic levels and eating habits.

Studies of the vertebrates reveal that a wide variety of other animals including dinosaurs, mammals, lizards, sphenodonts, choristodeirans, salamanders, snakes, small crocodilians, turtles, fish, lungfish, and frogs also inhabited the Morrison ecosystem. With the recent discovery and recovery of a new member of the Family Allosauridae from Dinosaur National Monument, we now know of at least three genera of these theropods that existed within the Morrison animal community. In addition to the documentation of the variety of vertebrates that occur in the Morrison Formation, a paleontologic reconnaissance survey was undertaken to determine the potential for fossil material within and near Arches National Park 
Dinosaur collections from the Morrison Formation were examined at several institutions in the United States to obtain baseline data needed to examine faunal evolution during the Late Jurassic. Collections were examined at the Museum of the Rockies (Bozeman, Montana), Brigham Young University (Provo, Utah), the University of Utah (Salt Lake City, Utah), and the Museum of Western Colorado (Grand Junction, Colorado). Also, computer records of Morrison dinosaurs were gathered.

The Morrison Ecosystem Project is thus well underway. The results from the first field season will be integrated so that ecosystem reconstruction will be constrained by a variety of evidence so that a more accurate picture will become available of the land that the dinosaurs roamed. 